\title{
4 Justice at Last: The Persecution of Homosexual Men and the Politics of Amends
}

On June 22, 2017, the German Bundestag passed the Act on the Criminal Rehabilitation of Persons Sentenced for Consensual Homosexual Acts after 8 May 1945 (StrRehaHomG), or Rehabilitation Act (BT PLP 18/240 2017). The Act repealed convictions under Paragraphs 175 and 175a of the FRG Criminal Code and Paragraph 151 of the GDR Criminal Code that were issued after 8 May 1945 in what became the Federal Republic of Germany and the German Democratic Republic, respectively. It rehabilitated men who had been convicted by German courts of consensual homosexual acts after the end of the Nazi regime ${ }^{1}$. Furthermore, it granted a right to reparations in the amount of 3,000 Euros per conviction plus 1,500 Euros per year or part thereof that those affected spent in custody. Later, the right to reparations was also extended to men who had been charged with homosexual acts but not convicted.

The Act was hailed by the government and the public alike as a major move to end discrimination against homosexuals and provide justice for those who had suffered from it in the past. The Federal Minister of Justice at the time, Heiko Maas, called the convictions "iniquities of the constitutional state" (Schandtaten des Rechtsstaates) (SZ 2017), maintaining: "From today's viewpoint, the former convictions are blatantly wrong. They deeply violate the human dignity of every person convicted" (SZ 2017). The Federal Family Minister, Manuela Schwesig, added that the Act was an "important signal for all homosexuals in Germany that discrimination and prejudice against them have no place in our society today or in the future" (SZ 2017).

The Law did not suspend all convictions, however: It did not rehabilitate those men who were sentenced for sexual interaction with boys under the age of 16 . As the age of consent between persons of different sexes in Germany is not 16 but 14, this was seen as ongoing discrimination by some (BT PLP 18/240 2017, 24606 C). 
The Rehabilitation Act, I argue, is both exceptional and paradigmatic. It is exceptional with regard to (West) German reparation policy in that it grants official rehabilitation and reparations to persons harmed by state wrongdoing after 1945. Thus, by enacting the Rehabilitation Act, the democratic state acknowledged its own systematic wrongdoing-and not only that of its predecessor, the Nazi state. Moreover, the democratic state acknowledged that it had in fact continued Nazi policy for decades: The Federal Republic had continued to apply a law dating back to 1935 and continued to persecute homosexuals, albeit in a mitigated form. By acknowledging this continuity, the state departed from the binary classification system that had structured West German reparation policies until then, namely the classification of reparation claims into those that referred to 'typical Nazi injustice' and those that did not. Within this system, the former counted as justified, the latter not; the former constituted an entitlement to reparations, the latter at best the possibility to apply for hardship compensation. The category of 'typical Nazi injustice' was circumscribed in temporal and semantic terms: In temporal terms, it was confined to the period of Nazi rule, demarcated by precise dates of beginning and ending. In semantic terms, 'typical Nazi injustice' referred exclusively to acts motivated by Nazi ideology. Conversely, this means that forms of repression, infringements and persecution that were not exclusively committed by the Nazi state, such as imprisoning homosexuals, by definition did not count as typical Nazi injustice and thus did not constitute entitlement to reparations. By definition, then, the post-war German state could not commit wrongs, at least not of a kind that would constitute an entitlement to reparations. The Nazi state was constructed as the state of exceptional evil, the post-war (West) German state as the state of democratic normality, and both as mutually exclusive. The Rehabilitation Act breaks with that dichotomy, which is an exceptional case in German reparation policy. There is no other case in which the Federal Republic has acknowledged a continuation of Nazi practices and granted reparations for it.

At the same time, the Act is paradigmatic insofar as it demonstrates the performative power of reparation policies: As the statements by Maas and Schwesig make clear, what is at stake is the moral, legal and political self-image of German society: What kind of society do we want to be? What kind of society do we not want to be any longer? What are our fundamental legal and ethical principles? Like any reparation policy, the Rehabilitation Act articulates past, present and future. By passing the Rehabilitation Act, the German state declared that consensual sex is a basic individual right that is protected 
by the German constitution and that applies both to homosexual and heterosexual activities. The state confirmed the principle of equality before the law and consequentially condemned the criminalization of male homosexuality as an act of severe and unconstitutional discrimination. Homosexuality, it declared, is a matter of individual freedom. It does not pose a threat to the social and political order; on the contrary, it is discriminating against homosexuality that does so.

The path to that conclusion on the part of the state was, however, a long one. To show how long, I will briefly recall the Nazi persecution of homosexuals and the continuation of that persecution in the Federal Republic, and then reconstruct the struggle for reparations. I argue that the Nazi persecution of male homosexuals was driven by a biopolitical rationality that long persisted in the Federal Republic and that revolved around the idea that male homosexuality posed a threat to the health, strength and performance (Leistungsfähigkeit) of the body politic and thus had to be eradicated. The state failed to recognize the persecution of homosexuals for what it was-a severe and systematic state offence-for as long as this biopolitical construction of homosexuality endured. The 2017 Rehabilitation Act has made it manifest that this is no longer the case and that the biopolitical construction of certain people as a threat to national health, strength and performance no longer applies to homosexual men.

\section{1 "Exterminating the Disease": The Nazi Persecution of Homosexual Men}

When the Federal Republic came into being, it inherited inter alia Paragraphs 175 and 175a of the Criminal Code that had been enacted under Nazi rule in 1935. Before 1935, Paragraph 175 already penalized 'unnatural fornication' between males, but in 1935, the word 'unnatural' was removed so that men could be convicted for each and every activity considered to go against a "general sense of modesty and morality", including for instance "lewd glances" (Reichsgerichtshof 1940 quoted in Rinscheid 2013, 254). In addition, a new Paragraph 175a was created specifically to penalize certain forms of homosexual activities, namely threatening a man into homosexual acts, homosexual acts within a relationship of dependency such as a service or employment relationship, and homosexual acts between men over and under the age of 21 years. These provisions were the first in German history to introduce an age of consent for 
male homosexual acts that differed from that for heterosexual sex (Zinn 2018, 282). The homosexual acts specified in Paragraph 175a were punishable with up to ten years in penitentiary. In October 1936, Himmler established the Reich Central Office for Combating Homosexuality and Abortion (Reichszentrale zur Bekämpfung der Homosexualität und der Abtreibung) as a central instrument to detect and register homosexual men throughout the Reich. Upon the enactment of the revised Paragraph 175 and the establishment of the Office, the number of prosecutions, convictions, raids and arrests increased sharply.

Between 1935 and 1945, ordinary courts alone launched nearly 100,000 indictments according to Paragraphs 175 and 175a, and about half of the men charged were convicted (Zur Nieden 2009, 289). Some 6,500 additional convictions were issued by special courts such as martial courts (Grau 2014, 44). In 1940, moreover, Himmler decreed that the criminal police were to place all homosexual men who had seduced more than one partner in 'preventive detention' (Vorbeugehaft) after they had served their prison sentences (Bastian 2000, 58). Thousands were deported to concentration camps, and only a minority survived (BT Drs. 14/2984 (neu) 2000, 1). According to historical research, the death rate of homosexual men in the camps was about 60 percent (Zinn 2018, 319). Exact figures, however, are still lacking.

There is some dispute about the goals and the logic of this persecution ${ }^{2}$. Talk of a 'homocaust' among gay movements in the 1980s suggested that it aimed at a complete elimination of homosexuals, analogous to the attempt to eliminate Jews. Though historical researchers today tend to agree that this was not the case (Bastian 2000, 87ff.; Grau 2011, 145), leading Nazi functionaries, above all Heinrich Himmler, did indeed call for the extermination of homosexual men. His goal was nothing short of "exterminating the parasites of the people" (die Ausmerzung der Volksschädlinge) and "removing the predisposed, that is the centre of the epidemic, from the body of the people" (Himmler quoted in Zinn 2018, 295). Yet only a small fraction of homosexual men were in fact seized and detained (Bastian 2000, 88f.; Grau 2014; Zinn 2018, 304). The actual policy was directed at eliminating homosexuality as a visible way of life rather than eliminating each and every homosexual man. From 1934 onwards, Himmler made the issue a top priority. For him and other Nazi leaders, homosexuality was abnormal, deviant and sick, and homosexuals were alien to the ethnic community (Gemeinschaftsfremde), together with prostitutes, homeless 2005. 
people, vagrants and others labelled as 'asocial' or 'work-shy'. However, rather than simply being treated as a subcategory of 'asocials', male homosexuals were constructed as a separate target group, persecuted by specifically designed instruments of detection, registration and extermination. What constituted his specificity?

One pervasive feature of Nazi homophobia was the preoccupation with population policy (Pretzel 2002, 25; 34). In that vein, the official rationale for revising Paragraph 175 in 1935 proclaimed: "The new state, which strives for a nation that is strong in number and strength and morally healthy, must vigorously confront all unnatural sexual activity." (Quoted in BT Drs. 14/2984 (neu) 2000 , 1) Himmler in particular was obsessed with population policy, as indicated inter alia by his linking of the war against homosexuality with that against abortion (Grau 2011, 40). In February 1937, Himmler gave a speech to SS group leaders in Bad Tölz in which he laid out the grounds for eliminating homosexuality ${ }^{3}$ and declared that tolerating the existence of one to two million homosexuals would mean "that our people will be wrecked by this epidemic" because the lack of "sexually able men will disrupt Germany's gender economy and become a disaster" (Himmler quoted in Zinn 2018, 291).

The preoccupation with population policy, however, does not explain why only homosexual men were targeted. Female homosexuality was ostracized as well (Eschebach and Ley 2012; Schoppmann 1997) and condemned as unnatural and morally unhealthy. The clubs, journals and meeting points of lesbian subculture were destroyed, but homosexual women were not systematically registered, charged, detained and murdered for same-sex activity. Female homosexuality was not constructed as a threat. Male homosexuality, in contrast, was constructed as an epidemic that threatened to undermine both the Volksgemeinschaft and the state. Unlike female homosexuals, male homosexuals were ascribed a seductive power, particularly among youth, and it was this power that made them so dangerous (Zur Nieden 2005). Accordingly, the Nazis concluded, the state had to:

... combat same-sex fornication between men particularly forcefully, as experience has shown that it has a tendency to spread epidemically and that it exerts a considerable influence on the entire thinking and feeling of the speech on this topic (Zinn 2018, 291). 
circles concerned. (Official rationale for the revised Paragraph 175 of 1935 quoted in BT Drs. 14/2984 (neu), 2000, 1)

Similarly, the SS newspaper The Black Corps declared in 1937: "Forty thousand abnormals that could very well be eliminated from the ethnic community (Volksgemeinschaft), are, if left free, capable of poisoning two million" (Das Schwarze Korps quoted in Zinn 2018, 310).

Thus, male homosexuality was constructed as a contagious disease that, unless vigorously fought against, would spread among the male population. Notably, as Zinn points out, the Nazi state was heavily reliant on all-male organizations such as the SS, and these were imagined as being particularly vulnerable to the epidemic. Germany, Himmler insisted, was a men's state, and it was on the verge of self-destruction due to male homosexuality (Zur Nieden 2005). According to this imaginary, male homosexuality, equipped with its seductive power, was creating secret communities within organizations, a state within the state (Zinn 2018, 291f.; 295). Yet what was most disturbing for Himmler was the idea of homosexual men as soft, weak, spineless, cowardly, and mentally ill, tending to substitute an erotic principle for the principle of achievement (Leistungsprinzip) (Zinn 2018, 292; 294): "Homosexuality thus brings down every achievement (Leistung), every advancement (Aufbau) within the state and destroys the foundations of the state." (Himmler quoted in Zinn 2018, 292)

The word 'Leistung' does not easily translate into English. It connotes not only achievement but also merit and performance; thus, it may refer to results but also the activity of making an effort or to the capacity for achieving results. The notion of Leistung, then, alludes to notions of efficiency, productivity, functionality, and strength and refers to results, activities and capabilities at the same time. For Himmler and other Nazi leaders, male homosexuality endangered the Leistungsprinzip, the basis of a strong, powerful, healthy state. Himmler therefore demanded that homosexual members of the SS be degraded, expelled and imprisoned. After serving their sentences they should be sent to concentration camps and "shot dead on the run" (Himmler quoted in Zinn 2018, 292). Hence, male homosexuality was constructed as a sex-related biopolitical threat, a contagious disease that undermined both the state and the Volksgemeinschaft and their health, strength and fitness. It was this biopolitical imaginary that motivated the Nazi persecution of homosexuals. As we shall see, it did not dissolve in 1945. Rather, it informed both the contin- 
ued policy of criminalizing male homosexuality and, indirectly, the exclusion of homosexual Nazi victims from the post-war reparation scheme.

\subsection{Normal Persecution: Paragraph 175 in the Federal Republic}

Seventy years before the Rehabilitation Act was passed, in 1957, the Federal Constitutional Court issued a ruling on the matter of male homosexuality. The Court ruled that Paragraphs 175 and 175a of the Criminal Code did not violate the constitutional principles of personal freedom and equal protection before the law. The main rationale for this conclusion was that male homosexual acts violated moral law (das Sittengesetz) (BVerfGE 6 1957, 1).

The ruling rejected the constitutional complaint of two men, mentioned as Günther R. and Oskar K., who had been convicted for homosexual acts under Paragraphs 175 and 175a by the District Court of Hamburg in 1952. These paragraphs, the claimants held, dated back to 1935; thus, they were Nazi law and as such incompatible with the Basic Law, the West German Constitution. Consequently, they argued, Paragraphs 175 and 175a should be abolished and their convictions repealed. The Constitutional Court, however, refuted both claims; it denied that Paragraph 175 was Nazi law on the grounds that the 1935 law, although enacted under Nazi rule, was not a typical Nazi law. Not all laws dating back to the Nazi period were regarded as typical Nazi law. Therefore, the judges concluded that upholding Paragraphs 175 and 175a would not constitute a continuation of Nazi law and accordingly denied the two men legal rehabilitation.

Importantly, the Court did not engage with the fate of homosexuals under Nazi rule; the judges made no effort whatsoever to establish the facts of the persecution, let alone the logic behind it. Instead, they demonstrated at great lengths that banning male homosexuality had a long tradition in German law and that the Nazi ban was therefore merely one episode amongst others. They cited the Old Testament, the Constitutio Criminalis Carolina, Prussian law, various other German state laws before 1871, and others in order to bolster the claim that penalizing male homosexuality was perfectly normal for a political entity. In this way, the Court ultimately normalized the criminalization of male homosexuality, dissociated it from the Nazi past and categorized it as an exercise of normal statecraft.

In addition, the Court pointed to the fact that Paragraphs 175 and $175 \mathrm{a}$ were not listed in Control Council Law No.1. This law, established by the Allied 
Control Council in September 1945, expressly repealed a number of Nazis laws and legal provisions for being "of a political or discriminatory nature upon which the Nazi regime rested" (Control Council Law No. 1 1945). It did not list Paragraphs 175 and 175a, Criminal Code, nor, for instance, the Law for the Prevention of Offspring with Hereditary Diseases, which had allowed for forcible sterilizations. Thus, the Constitutional Court concluded, the Allied Forces had not considered Paragraphs 175 and 175a to be specific to Nazi law.

Finally, the Court ruled, Paragraphs 175 and 175a were not invalidated by the Basic Law. The Federal Republic was the legal successor of the Nazi state and as such inherited the existing laws from the time prior to 1949-except for those found incompatible with the Basic Law (BVerfGE 6 1957, 20). Neither the Parliament nor the Constitutional Court found Paragraphs 175 and 175 a to be incompatible with the Basic Law, so they remained in force.

In terms of content, the claimants argued that treating male homosexuality differently from female homosexuality violated the constitutional guarantee to equality before the law (Art. 3 GG). However, the Court denied this claim as well. It referred to a range of expert testimonies from medicine, psychiatry, social work, the police, and forensics that unanimously confirmed that male homosexuality was different from female homosexuality. The former, the testimonies agreed, was more intense, more aggressive, more visible, more promiscuous, more averse to marrying and having children, and not least more contagious and hence more dangerous to society (BVerfGE 6 1957, 21ff.). Due to its contagious power, they reasoned, male homosexuality was more widespread and more closely linked to venereal diseases, prostitution and crime and thus more dangerous to society. Unless the state took action to curb and control it, it would drain the life out of the population and debilitate it in terms of size, strength, health, and moral condition. Young people, as several of the invited experts claimed, were especially vulnerable to homosexual seduction; therefore, the state was called upon to protect its youth against this imminent threat.

Regarding the constitutional guarantee of personal freedom, the Court simply stated that it only applied within the confines of the moral law (Sittengesetz), whereas male homosexuality clearly violated the moral law (BVerfGE 6 1957, 30). In principle, then, the Court declared, personal freedom was a basic right, and, also in principle, the right to unrestricted personal development included one's sexuality, but this did not apply to homosexual men. Homosexual men were denied the right to personal freedom and equal treatment. The norm, according to the implicit logic, only applied to 'normals', not 
to 'abnormals'. The Court effectively stripped homosexual men of their basic constitutional rights and, as a result, of social status, their livelihood, and opportunities in life. In this sense, homosexual men in post-war Germany were homini sacri (Agamben 1998): governed and subjugated through law but deprived of legal status and protection. To bolster its reasoning, the Constitutional Court quoted the draft Criminal Code of 1927:

The legislator should ask himself whether Paragraph 175, despite the hardships to which its application may lead and its limited practicability, does not constitute a barrier which may not be removed without harming the health and purity of the life of our people (unseres Volkslebens). [...] If this aberration continues to spread, it leads to the degeneration of the people and the decline of its strength [...] (BVerfCE 6 1957, 30f.)

We see here that the construction of male, and only male, homosexuality as a biopolitical threat did not originate in Nazi policy. The Nazis used it as a rationale for mass murder, but the construction as such neither arose nor ended with the Nazi regime.

The 1957 ruling set the tone for the following years, providing the main reference for legal and political decisions on the issue. We find all of its key elements reiterated in a draft criminal code presented by the Adenauer government in 1962. Eventually, the draft was rejected by the Bundestag, but it merits study as it set out the key elements of the biopolitical logic that motivated the preservation of Paragraph 175. It conceded that same-sex activity as such did not violate any legal rights or interests (Rechtsgüter). Nonetheless, the draft went on, the state was entitled to penalize behavior that was ethically despicable and shameful, as was the case with male homosexuality. After all, it was inherently contagious and spread particularly among young people. Consequently, homosexual communities would form and propagate within public services and institutions such as the police or the army and corrupt these from within (BT Drs. 4/650 1962, 377). Female homosexuality would not have this rampant, community-building, institution-corrupting power (BT Drs. 4/650 1962, 378). Therefore, the government concluded:

More than in other areas of law, the legal system has the duty, vis-à-vis male homosexuality, to use the morality-forming power of the penal law to build a dam against the spread of a vicious activity which, if it were to take hold, would pose a serious threat to the healthy and natural order of the life of the people. (BT Drs. 4/650 1962, 377) 
After all, historical experience had shown: "Where same-sex fornication has spread and assumed huge proportions, the result has been the degeneration of the people and the decay of its moral powers" (BT Drs. 4/650 1962, 377).

Paragraphs 175 and 175a did not exist only on paper; they were applied extensively. Criminal prosecution continued on a large scale: In the Federal Republic between 1945 and 1965, there were approximately 100,000 indictments and more than 44,000 convictions under Paragraphs 175 and 175a-near the number of criminal cases under Nazi rule (Zur Nieden 2009, 289). By way of comparison, in the fifteen years of the Weimar Republic, 'only' 9,375 convictions had taken place (Burgi and Wolff 2016, 22). It is important to note that not only a conviction, but even an indictment could be devastating. People could lose their jobs and their housing; they could be expelled from religious or other civil society associations. Self-help groups and sub-cultural or political associations were not permitted, so homosexual men were severely deprived of their civic and political rights (Burgi and Wolff 2016, 31).

Paragraphs 175 and 175a remained in place in the Federal Republic until the general revision of the Criminal Code in 1969. In 1973, further revisions reduced the list of sanctionable offences to sexual activities between men over and boys under eighteen years. The age of consent for heterosexual activities was sixteen at that time. In a ruling of October 1973, the Constitutional Court confirmed that this differential treatment was constitutional, citing the ruling of 1957. Male homosexuality, it reiterated, was fundamentally different from both lesbian and heterosexual sexuality, as several scientific experts had verified in 1957. Again, the main reason cited was that young men needed state protection from homosexual seduction, which would otherwise spread and damage their personal lives and development (Burgi and Wolff 2016, 31).

The GDR completely abolished Paragraphs 175 and 175a in 1968 and thereby, as Günter Grau points out, was the first polity in German history to decriminalize consensual sex between men (Grau 2011, 154). In the Federal Republic, Paragraph 175 remained in force until 1994. It was abolished solely in the context of German unification and the need to harmonize the two German Criminal Codes (Grau 2011, 157).

Thus, the Federal Republic deliberately maintained the 1935 Nazi law and deprived homosexual men of basic constitutional rights. Major state institutions subscribed to the biopolitical construction that male homosexuality was a contagious force that caused mental illness, weakness, venereal diseases, prostitution, and crime and that threatened to undermine the strength and fitness of state and society. In short, the institutions of the Federal Republic 
maintained the Nazi law because they shared the biopolitical rationality that informed it.

It was due to this continuity in biopolitical rationality that homosexual victims of Nazi persecution were excluded from post-war reparations, as I will show in the following pages.

\subsection{Banned from Reparations}

After 1945, homosexual men were effectively excluded from reparations. To understand how and why this happened, we need to understand the architecture of the West German reparation scheme and its inbuilt distinction between normal statecraft and exceptional evil. Within this framework, the type of violations that I have termed injuries of normality, such as the persecution of homosexuals, selective sterilization, and the persecution of 'asocials', would qualify as normal statecraft, not as exceptional evil. As explained in Chapter 1 , the concept of injuries of normality refers to systematic human rights violations and acts of degradation, stigmatization and persecution of persons deemed not to conform with underlying standards of normality, health, fitness, productivity or usefulness for the community. Injuries of normality follow a biopolitical rationality of safeguarding and improving the fitness, functionality and productivity of the collective body, a rationality which, as such, was not limited to the Nazi regime. Nazi biopolitics was exceptionally murderous, but the biopolitical rationality that informed systematic injuries of normality was not utterly alien to German governments before or after 1945 . In fact, the way that West German courts and governments dealt with the reparation claims of those affected by such injuries of normality demonstrates that they shared the underlying rationality and considered it quite normal for a state, for instance, to defend itself against the debilitating power of male homosexuality. This underlying attitude is reflected in the architecture of the West German reparation scheme.

There were, and still are, two possible ways for Nazi victims to achieve compensation in the Federal Republic: via the Federal Indemnification Act (Bundesentschädigungsgesetz, BEG) of $1953^{4}$ and via the 1957 General Law on 
Consequences of the War (Allgemeines Kriegsfolgengesetz, AKG) with the Hardship Funds established under it in the 1980s. Importantly, only the Federal Indemnification Act grants entitlement to reparations for an injustice suffered, subject to territorial restrictions ${ }^{5}$, whereas the AKG was meant to provide compensation for a damage that occurred in the context of the war. The legislators were well aware that the BEG did not grant the right to reparations to all Nazi victims; this had never been their declared intention (Hockerts 2001). Thus, a distinction had to be made between what should and what should not constitute an entitlement to reparations. The legislators deliberately decided to make reparations under BEG available only for typical Nazi injustices, with only specific forms of Nazi persecution qualifying as typical Nazi injustices. For this reason, the BEG conclusively defines who qualifies as a victim of Nazi persecution, namely someone who was persecuted for reasons of political opposition to the Nazi regime or for reasons of race, religion or ideology (Weltanschauung) (BEG \$1(1)). This definition excluded the victims of forced sterilization, homosexuals, so-called 'asocials', so-called 'professional criminals', deserters, forced laborers and many others, regardless of what they suffered. Even if they had suffered deportation, detention in a concentration camp, injuries, mutilation or murder, these acts as such did not qualify as Nazi persecution. The question for the BEG was not whether a persecution occurred, but on what grounds. The critical distinction for the BEG was not the severity of offenses but the subjective motive behind them (Giessler 1981, 9). Put differently, the law-makers in the 1950 s distinguished between legitimate and illegitimate motives for persecution-a distinction which came down to the question of whether they themselves could or could not accept them.

State measures to curb homosexuality, inheritable diseases or asocial behavior were not considered typical Nazi injustice (Hockerts 2001, 201). Accordingly, the legal literature after 1945 explicitly justified their exclusion from reparations under BEG. After all, it was argued, Paragraph 175 had not been

BEC), passed on 29 June 1956, which entered into force retroactively on 1 October 1953 (Federal Ministry of Finance 2019, 10).

5 The Law is based on the so-called territoriality principle, which requires that claimants must have had a "spatial relationship" to the German Reich. This includes, roughly speaking, German citizens and persons who lived in within the 1937 German borders. It does not include persons who suffered from Nazi crimes elsewhere (Brunner, Frei, and Coschler 2009, 25ff.). 
in place for reasons of race or political opposition but for reasons of expediency or security (Burgi and Wolff 2016, 33). The German government agreed. As late as 1986, a report by the Federal Government to the Bundestag explained:

The penalization of homosexual activity in criminal proceedings conducted in accordance with criminal law provisions is neither Nazi injustice nor incompatible with the rule of law. [...] Therefore, convictions imposed in criminal proceedings conducted in accordance with the law and executed in the regular course of justice cannot be compensated as a deprivation of liberty. (BT Drs. 10/6287 1986, 40)

The fact that consensual sexuality was persecuted did not constitute an injustice because it was motivated by acceptable reasons-reasons that policymakers and jurists of the Federal Republic could share. They, too, thought that male homosexuality constituted a danger to youth, that it was contagious and debilitating, caused moral weakness, physical and mental illness, prostitution and crime. In short, they shared the biopolitical construction of male homosexuality as undermining the health and fitness of state and society.

After the BEG, the General Law on Consequences of the War (AKG) formed a second possible track to reparations. It was passed in November 1957 and was intended to govern the claims of those who had been harmed by the Nazi regime but were not eligible for reparations under the BEG. However, as Hans Günter Hockerts states, the hurdles were high and the application deadlines tight; as a result, until the establishment of new hardship funds in the 1980s, the numbers of recipients from groups not mentioned in the BEG were close to zero (Hockerts 2001, 201). Under the hardship funds established in the 1980s, claimants could receive a one-time allowance of 5,000 Deutschmarks or, in particularly severe cases, monthly allowances. Yet, even then, the number of successful applications by homosexual men remained negligible. By 31 December 2018, a total of twenty applications had been submitted by persons who had suffered persecution as homosexuals, and eight of these were approved (Federal Ministry of Finance 2019, 29). A total of five applications had been submitted for monthly allowances; two were approved (Federal Ministry of Finance 2019, 30).

To conclude, the distinction between those who were entitled to reparations and those who were not ultimately rested on the new state's attitude towards the former's motives for persecution. With respect to male homosexuality, the political and legal elite of the Federal Republic predominantly shared the Nazi assumption that male homosexuality was debilitating and 
contagious and thus a danger to state and society. For them, criminalizing and controlling homosexuality was an entirely reasonable thing to do, even if some measures, such as detaining people in concentration camps, may have constituted an undue hardship in some cases. The construction that motivated the penalization of male homosexuality was essentially the same as that of the Nazi state; in this respect, the democratic state shared the Nazi state's motives, if not quite its methods.

\subsection{Regret and Reluctance}

After decades of struggle, Paragraph 175 was finally abolished in 1994. It was not until then that the Federal Republic began to distance itself from the persecution of homosexuals and to acknowledge that it had been a severe case of wrongdoing that required redress. After another four years, in 1998, the Bundestag passed the Law to Annul Unjust Sentences Imposed During the National Socialist Administration of Criminal Justice (NS Annulment Act; NS-AufG), which rescinded all unjust NS criminal judgements without case-by-case review. Yet the appendix to the law that specified which types of sentences were defined as 'unjust' did not include Paragraphs 175 and 175a, meaning that convictions according to Paragraph 175 and 175a, whether before or after 1945, were not annulled at that point.

Two years later, in December 2000, the Bundestag passed a unanimous resolution that stipulated that the criminalization of consensual homosexual activities after 1945 had been a violation of human dignity (BT PLP 14/140 2000). The Bundestag issued an apology:

The German Bundestag confirms its conviction that the honor of the homosexual victims of the Nazi regime must be restored. The Cerman Bundestag regrets that the National Socialist version of Paragraph 175 remained in force without change in the criminal law of the Federal Republic of Germany until 1969. It apologizes for the continuing criminal prosecution of homosexual citizens until 1969, whose human dignity, opportunity for personal development, and quality of life were severely impaired by the threat of criminal prosecution. (BT Drs. 14/2984 (neu) 2000, 2)

The decision, however, had no immediate consequences in terms of rehabilitation or reparations; the majority of MPs at the time were not ready to annul the convictions issued by the Nazi courts, let alone those of the Federal 
Republic. One concern was that this might create a precedent for further rehabilitation claims, as MdB Jörg van Essen (FDP) explained:

... after 1945, too, people suffered terribly with the consequences of a conviction going far beyond what punishment should actually do, namely leading to the destruction of all opportunities in life, to social ostracism. We have to admit that, unfortunately, this has happened in a similar way in many other areas too. We have had terribly dismaying sentences [...] that make us clench our hands over our heads. People were sent to prison for several months for everyday crimes. There were incredibly harsh sentences in this area in particular, because much of the injustice that had been sown during the Third Reich had an aftermath. That is why it is extremely difficult for us, from today's point of view, to judge the time after 1945 by saying: We declare this to be wrong; if we started in one area but did not extend it to other areas, we would not really achieve justice. I suspect that there are many areas in which, from today's point of view, we have to say that we cannot agree with the judgments of that time. (BT PLP 14/140 2000, 13744 A-B)

At stake, then, was the temporal-substantive demarcation that had been erected to separate the present from the past, the constitutional state from the state of injustice, ordinary statecraft from extraordinary evil. The majority of Parliamentarians could not yet bring themselves to acknowledge the permeability of that demarcation line and concede that numerous forms of injustice had passed through it and continued to operate under the new democratic regime.

The men who had suffered Nazi persecution as homosexuals would wait two additional years until, in May 2002, the Bundestag finally passed the Act to Amend the Law to Annul Unjust Sentences Imposed during the National Socialist Administration of Criminal Justice-against the votes of the CDU/CSU and FDP (Burgi and Wolff 2016, 34). Through this act, those who had been convicted under Paragraphs 175 and 175 a by the Nazi state received rehabilitation-but not those convicted under the same law after 1945.

In the following years, the Greens and the Left in Parliament again launched attempts to achieve rehabilitation and reparations for those convicted for consensual homosexual acts after 1945 (BT Drs. 16/11440 2008; BT Drs. 16/10944). In 2009, their motions were rejected by the votes of the CDU/CSU, SPD and FDP in the Bundestag. The CDU/CSU, SPD and FDP were willing to annul the convictions passed by the Nazi courts but not those passed by the courts of the Federal Republic, even though the Bundestag had 
stated in 2000 that the convictions before and after 1945 violated human dignity. Obviously, the question was not whether a severe human rights violation had been committed, but by whom.

The arguments against repealing the post-1945 convictions mainly referred to constitutional issues. In a constitutional state, opponents argued, the parliament was not entitled to repeal the rulings of the courts, for this would amount to breaching the separation of powers and the principle of legal certainty (Senatsverwaltung für Arbeit and Integration und Frauen 2011, 41). The events of the following years, however, showed that where there is a political will, there is also a constitutional way.

\subsection{From Injuries of Normality to Sexual Exceptionalism}

In 2011, the Berlin Senate held a conference offering an alternative view on the constitutional issues related to rehabilitation of and reparations for men convicted of homosexual activity after 1945. The Senate submitted reasoning according to which annulling post-1945 convictions was indeed constitutional (Senatsverwaltung für Arbeit and Integration und Frauen 2011). In 2015, the Bundesrat passed a resolution calling upon the federal government to draft a new law to rehabilitate the men convicted for consensual homosexual acts after 1945 on the grounds that these convictions had violated human dignity (BR Drs. 189/15 (Beschluss) 2015).

Instrumental in this respect was also the legal opinion of Martin Burgi and Daniel Wolff on behalf of the Federal Anti-Discrimination Agency on rehabilitation for post-1945 convictions and the issue of constitutionality (Burgi and Wolff 2016). The opinion took constitutional concerns about legal certainty and separation of powers seriously, but also clarified that a general annulment would not violate either of them. The first of these concerns referred to the point that, in a constitutional democracy, neither the government nor parliament is permitted to interfere with the decisions of the judiciary. If the parliament were to issue a blanket annulment of an entire set of court rulings, this would amount to breaching the separation of powers and encroaching on the principle of legal certainty. Burgi and Wolff, however, countered that such an encroachment could be justified in this case given that it would refer to an exceptional matter. Firstly, they argued, the convictions at stake affected a clearly demarcatable group of individuals, and secondly, they constituted an exceptionally severe infringement of these individuals' basic rights, namely 
"an intervention in the inviolable core domain of a person's private life as covered by the fundamental right to free development of personality provided for in Article 2(1) Basic Law, in conjunction with Article 1(1) Basic Law" (Burgi and Wolff 2016, 10).

While there may have been other convictions after 1945 that referred to offenses no longer criminalized today, such as procuring and adultery, issuing a blanket rehabilitation of men convicted under Paragraphs 175 and 175a would not set a precedent and would not entail a series of further claims to rehabilitation, since the impact of these infringements differed: "The stigmatization and intense repression by and within society that was predominantly and typically suffered by individuals convicted under Section 175 StGB is in this regard unparalleled" (Burgi and Wolff 2016, 11).

Both the government and the parliament finally adopted this line of reasoning. In 2016, Federal Minister for Justice and Consumer Protection Heiko Maas (SPD) announced that the government was preparing for the legal rehabilitation and reparations for those convicted for consensual homosexual acts after 1945 (BMJ 2016). On 22 June 2019, the Bundestag adopted the Rehabilitation Act unanimously.

Proponents of rehabilitation and reparations could draw support from the European Court of Human Rights, which, beginning in 1981, had issued a series of rulings condemning the criminalization of consensual homosexuality (Johnson 2013). The Court had greatly contributed to framing homosexuality as a human rights issue, evoking particularly the right to a private life, freedom of expression and non-discrimination as laid out in the European Convention for Human Rights. The new approach developed by the Court revolved around the notion of sexuality as "an essentially private manifestation of the human personality" (Johnson 2010). Sexuality, in these rulings, became an essential and inalienable aspect of human life, inextricably linked to intimacy and identity and as such valuable and worthy of state protection. Consensual homosexuality was no longer a matter of morality or a danger to the state but a matter of private life. The older, biopolitical notion of homosexuality as undermining the strength of the state gave way to a liberal-expressivist one in which homosexuality was seen as an individual lifestyle that allowed for the expression of one's own authentic personality. In the 2000 s, this new framework increasingly gained ground in German politics as well. Male homosexuality moved from the biopolitical register of diseases to the psycho-legal register of personhood and became a core element of gay men's personal identity, as Berlin Senator Dilek Kolat proclaimed: "Paragraph 175 threatened 
gay men at the core of their personalities, their sexual identities" (Senatsverwaltung für Arbeit, Integration und Frauen 2011, 6).

The notion of homosexuality as a core element of one's personality and thus as protected by the right to personal freedom formed the basis for the rationale for the Rehabilitation Act (BMJ 2016, 1). However, while the view that homosexuality was a matter of private life and not criminal law may have prevailed by then, it was still an exceptional step for the Bundestag to condemn its own former law, annul its consequences and grant reparations on the grounds that it had been unconstitutional. Therefore, as MdB Sabine Sütterlin-Waack (CDU/CSU) correctly proclaimed in the Bundestag's plenary debate, "Today we are bringing to an end a unique and unprecedented legal-political process with which we are also, in a sense, entering new constitutional territory" (BT PLP 18/240 2017, 24606D).

Indeed, for the first time, the German Parliament had passed an act of regret and redress for the continuation of a Nazi policy. In a gesture of exceptional self-critique, the state distanced itself not only from the wrongdoing of its predecessor but from its own wrongdoing. It acknowledged that its own democratic institutions had committed severe human rights violations that differed only in degree from those of the Nazi state. It conceded that there was only a gradual difference between the state of normality and the state of exceptional evil. To this day, no other group of Nazi victims has received a similar gesture.

One could say that, in the case of Paragraph 175, the continuity was most palpable since here the same policy was continued; people were charged, convicted and imprisoned and their lives destroyed by means of the same law. This is true, but the post-war German state also continued to operate workhouses, maintained sterilization verdicts for decades, denied victims reparations and rehabilitation, and justified these exclusions by citing medical grounds, security reasons or reasons of expediency. The state could have retrospectively distanced itself from these choices and did not. In the case of the persecution of homosexuals, the state in fact broke with the original motives of persecution; in other cases, it did not. In 2017, the German state no longer shared the biopolitical motive that had driven the criminalization of male homosexuality for so long. This motive had become incompatible with the political identity of the present state. The biopolitical construction of male homosexuality as a threat to the health, strength and performance of state and society was no longer evoked: it was dead. Instead, as in the rulings of the European Court of Human Rights, homosexuality was framed as a matter 
of intimacy, private life and personal development. In that respect, according to the dominant discourse, sexuality was a special, particular, exceptional facet of human activity that was intimately connected to the core of one's personality. It was exactly this idea of sexuality as a matter of privacy and of the fundamental core of personal existence that allowed the government to annul the convictions under Paragraphs 175 and 175a without setting a precedent for possible further lawsuits.

Due to this articulation of sexuality, privacy and authentic subjectivity, it was possible to set the case of homosexuality apart from any other potential area of post-1945 state wrongdoing. As Paul Johnson (2010) has shown for the European Court of Human Rights, reinterpreting homosexuality as a matter of human rights was accompanied by, or even enabled by, the construction of a "European homosexual subject" possessing "a true, authentic and congenital self" (Johnson 2010, 72). The same interpretational move allowed the German government to resolve their concerns that blanket rehabilitation of homosexuals might set in motion a series of further rehabilitation claims by other groups. Attaching homosexuality to the inner, inviolable core of one's personality allowed the law-makers to demarcate these rehabilitation claims from possible others and to constitute an acceptable exception to the general rule of non-interference with the judiciary. What appears as a normalization of same-sex activity on the one hand thus implies a kind of sexual exceptionalism on the other that makes sexuality an essentially private aspect of personal life. The new articulation of sexuality and privacy allowed for redrawing the line between justified and unjustified reparation claims and shielding the state against a possible avalanche of further reparation claims. In this vein, MdB Sabine Sütterlin-Waack (CDU/CSU) explained that the state had indeed continued to apply Nazi law in other instances as well, for example in the cases of adultery and matchmaking, and that this had caused considerable hardship, but that "neither adultery nor matchmaking amount to a massive intrusion into the core area of the personal right to design one's own private life" (BT PLP 18/240 2017, 24608A).

Homosexuality had thus been transformed from a political into a private affair, from a danger to state and society to a valuable resource deserving their protection. In 2017, it is a resource rather than a threat to society. Correspondingly, the object of state protection is no longer the moral and physical health of state and society but rather the healthy development of the individual personality. On a more speculative note, one could add that personal development has been promoted to a key resource for a state that increasingly 
relies on human capacities such as knowledge, creativity, and intelligence. The new individualistic, personalized variant of male homosexuality is not a political force that drains society and the state of their strength and productivity; rather, it is itself a source of strength and productivity. Homosexual men are no longer public enemies; they are no longer the others against whom 'we' have to defend our youth, our state and our society. Rather, the others are now the other states that proclaim homosexuals the public enemy, as MdB Gudrun Zollner (CDU/CSU) declared:

But we are also sending a signal as a society. Cermany takes a stand-against discrimination and against exclusion. We also want to send a positive signal beyond our national borders to countries where homosexuality is still heavily ostracized. (BT PLP 18/240 2017, 24612 C)

Thus, the Rehabilitation Act is a message to the world: Look: Germany is a liberal, modern, democratic state; it draws strength from its citizens' sexual self-expression and personal growth. Homosexuality is no longer an epidemic but a way of life, and one that is perfectly compatible with the moral, social and political order of the present state.

\subsection{Conclusion}

Why have almost none of the victims of the Nazi persecution of homosexuals received reparations while the post-1945 victims of Paragraph 175 have been awarded them? Admittedly, this chapter cannot answer the questions of which struggles were fought by whom and how between 1945 and 2017-or why some of them were more successful than others. Here, I can only point out what it was that changed.

Homosexual victims of Nazi persecution were excluded from the postwar reparation scheme because the judicial and the political elite of the new, democratic state shared the Nazis' motives for that persecution. They may not have adopted the full array of Nazi methods (although with Paragraph 175 they maintained critical parts of those methods), but they shared the rationale that had motivated the Nazi policy against homosexual men. This rationale had not been invented by the Nazis but dates back at least to the time of the Weimar Republic. The Nazis, principally Himmler, developed it into a powerful biopolitical delusion, composed of the following assumptions: all samesex sexuality is unnatural and shameful, but male homosexuality is particu- 
larly vicious, debilitating and aggressive; it is like an epidemic that, unless vigorously opposed, will spread and damage the people's health and sense of morality. It causes promiscuity, prostitution and crime and thereby damages society. Rather than an innate property, it is largely an acquired behavior caused by seduction, imitation and habit. Young people, according to this assumption, are particularly susceptible. In addition, homosexual men have the tendency to establish clandestine same-sex communities within existing institutions, rendering the core institutions of the men's state-the police and the military-particularly vulnerable. Sooner or later, homosexual communities will undermine the existing institutions and, given the vicious and debilitating character of male homosexuality, drain the strength and performance (Leistungsfähigkeit) of the state. Again, we see that Nazi biopolitics was not necessarily biologistic; its murderous force was not dependent on a biologistic epistemology.

This biopolitical construction did not dissolve in 1945. It was actively confirmed by the Constitutional Court in 1957 and by the Adenauer government in 1962 in its draft criminal code. The elites of the Federal Republic sustained the Nazi law that had served to deport, detain, degrade and kill tens of thousands of men because these elites continued to believe in the rationale that had motivated these atrocities. For the same reason, reparations to homosexual Nazi victims were denied. The West German reparation scheme was founded upon principles bound to contain the number of reparation claims in spatial, temporal and substantial terms: the territoriality principle, the restriction to the time between 1933 and 1945, and the definition of a victim of Nazi persecution as someone persecuted for reasons of political opposition, race, religion or ideology. Every reparation scheme draws distinctions between what constitutes a valid entitlement to reparations and what does not. In this case, the distinction ultimately referred to the perpetrators' motives; only those atrocities and infringements based on typical Nazi motivations should constitute an entitlement to reparations. Conversely, motives that reached beyond the Nazi regime in temporal, politico-geographical and/or substantial terms, such as motives that dated back further in time, were found operative in other countries as well, and/or were consistent with those of the ruling elites of the present state, would be excluded by design. Motives shared by the past and present elites included, for instance, the fight against communism and the fight against biopolitical threats and burdens (such as mental illness, disability, homelessness, and male homosexuality) that undermined the state's and society's strength and productivity. Within the post-war reparation scheme, 
injuries of normality such as the persecution of 'asocials', of people categorized as mentally ill or disabled, or of male homosexuals did not constitute an entitlement to reparations because and insofar as the post-war elites in politics and law effectively shared the Nazis' motives for persecuting these people. After 1945, they did not continue the camp system, they did not apply the Nazi sterilization law to sterilize people, they did not kill people for being mentally ill or homosexual, but in principle they shared the understanding that these people posed a threat or a burden to society that needed to be curtailed. Concerning homosexuality, the new state outright continued the Nazi policy in crucial respects.

In this case, however, the state also performed the most clear-cut break to date with former policy by acknowledging that this very continuity had constituted a systematic human rights violation that required redress. What made this break possible was the dissolution of the previous policy rationale: Male homosexuality is no longer conceived as a biopolitical threat. It has moved from the underworld of crime, clubs and clandestine communities into the core of one's personality, where it forms an essential element of personal development, self-expression and growth; this shift represents values most compatible with the contemporary, modern liberal state. The possibility, today, to freely express one's sexual identity, whether homosexual or not, is considered a source of, rather than a threat to, productivity and performance, and it is thus perfectly compatible with the social, moral and political values of the liberal state. No corresponding act of self-criticism and acknowledgement has occurred vis-à-vis 'asocials' or those who were forcibly sterilized. Concerning the latter, the present state has never officially acknowledged or expressed regret for the fact that it denied rehabilitation and reparation to victims for many years on the grounds that it did not, or does not, condemn the perpetrators' motives. 